\title{
IN VITRO PROPAGATION OF SOLANECIO BIAFRAE AND DETERMINATION OF GENETIC STABILITY OF PLANTLETS USING RAPD AND ISSR MARKERS
}

\author{
Jelili OPABODE*, Oluyemisi AKINYEMIJU \\ Department of Plant Science Obafemi Awolowo University Ile-Ife, Nigeria
}

Received: February 2016; Accepted: May 2016

\begin{abstract}
An efficient and reproducible micropropagation protocol of Solanecio biafrae (Oliv. \& Hiern) C. Jeffrey has been developed from nodal stem segments. Shoot development was obtained on Murashige and Skoog (MS) medium supplemented with benzylaminopurine (BAP) alone and in combination with zeatin and 1-naphthaleneacetic acid (NAA). Elongated shoots were rooted in the presence of zeatin or 3-indolebutyric acid (IBA) alone or in combinations. The highest number of explants forming shoots (100\%) as well as the highest number of shoots per explant (3.4) and the longest shoots $(22 \mathrm{~mm})$ were recorded on medium containing $4.0 \mathrm{mg} \cdot \mathrm{dm}^{-3} \mathrm{BAP}, 2.0 \mathrm{mg} \cdot \mathrm{dm}^{-3} \mathrm{NAA}$, and $1.0 \mathrm{mg} \cdot \mathrm{dm}^{-3}$ zeatin. About $76 \%$ of shoots formed roots on half-strength MS medium free of plant growth regulators. The best root formation (approximately $88 \%$ ) was recorded on the medium containing $1.0-1.5 \mathrm{mg} \cdot \mathrm{dm}^{-3}$ IBA. The micropropagated shoots with well-developed roots were efficiently acclimatized under greenhouse conditions. The random amplified polymorphic DNA (RAPD) and inter-simple sequence repeat (ISSR) amplification products were monomorphic in micropropagated plants and similar to those of mother plant showing their genetic uniformity. This is the first report of micropropagation of $S$. biafrae, which will facilitate in vitro mass propagation, conservation, and germplasm exchange of this endangered African vegetable.
\end{abstract}

Key words: genetic analysis; leaf vegetable; micropropagation; worowo

\section{INTRODUCTION}

Solanecio biafrae (Oliv. \& Hiern) C. Jeffrey called worowo is a traditional leaf vegetable in Africa, and it is a member of Asteraceae plant family (Adebooye 1996; Schippers 2000). The importance of $S$. biafrae as a leaf vegetable arises from its high nutritive values. Fresh succulent leaves of S. biafrae are used as a leaf vegetable in West Africa (Adebooye \& Opabode 2004). Leaves of S. biafrae contain per $100 \mathrm{~g}$ dry matter: crude protein $12.3 \mathrm{~g}$, crude fibre $11.8 \mathrm{~g}$, Ca $342 \mathrm{mg}, \mathrm{P} 39 \mathrm{mg}$, and Fe $52 \mathrm{mg}$ (Adebooye 1996). Furthermore, medicinal value of S. biafrae is being exploited as leaf extract to stop bleeding from fresh cuts and sore treatment (Adebooye 2004). S. biafrae is being used as a biological control agent for weed suppression in plantation crops. It has considerable potential as a cash income earner, enabling the poorest people in the rural communities to earn a living from its domestication. Agronomically, S. biafrae is well adapted to harsh climatic conditions and diseases. Moreover, it is easier to grow in comparison to its counterparts, such as cabbages and broccoli (Adebooye \& Opabode 2004).

The existence of $S$. biafrae is being threatened despite its nutritional, medicinal, and agronomical importance because of it being considered a weed by researchers and thus the tendency to eradicate and not conserve it (Adebooye \& Opabode 2004). S. biafrae is propagated usually by stem cuttings. Little is known about the distribution of the species as its genetic diversity is not investigated. The biology of S. biafrae and its nutrition and response to abiotic stresses such as water, temperature, and nutrients, as well as protection against diseases and pests has not been adequately investigated and described (Adebooye 2004; Opabode \& Adebooye 
2005). Lack of quality seeds and seed dormancy are other constraints to sustainable production and utilization (Adebooye 2004). S. biafrae perpetuates itself untended and as a volunteer crop. To prevent $S$. biafrae from becoming extinct, there is an urgent need to use micropropagation to solve problems associated with its production (Adebooye 2004; Opabode \& Adebooye 2005). Establishment of a micropropagation protocol will ensure mass propagation of the vegetable and reverse its status of being a threatened species within a short time. The objective of this study was to establish a micropropagation protocol from the nodal segments and confirm the genetic fidelity of plants raised in vitro by random amplified polymorphic DNA (RAPD) and inter-simple sequence repeat (ISSR) markers.

\section{MATERIALS AND METHODS}

\section{Plant materials and surface sterilization}

The morphotype of S. biafrae with green stem was used for the study. Seventy donor plants were raised from stem cuttings at the screen house of the Faculty of Agriculture, Obafemi Awolowo University, Ile-Ife, Nigeria. Young plants were treated with $0.5 \%(\mathrm{w} / \mathrm{v})$ Bavistin $50 \mathrm{DF}$ (carbendazim), a broadspectrum fungicide. Nodal segments $(1-2 \mathrm{~cm})$ from actively growing plants were excised and the surfaces sterilized with $0.1 \%$ mercuric chloride $(\mathrm{w} / \mathrm{v})$ for 3 min followed by four to five rinses with sterile distilled water.

\section{Culture media and conditions}

Basal medium (BM), which consisted of fullstrength Murashige and Skoog (MS) (Murashige \& Skoog 1962) mineral salts (Sigma-Aldrich, USA), $0.8 \%$ agar, and $3 \%$ sucrose, was used for shoot induction and elongation experiments. Rooting medium (RM), which consisted of half-strength MS salts, $0.8 \%$ agar, and $3 \%$ sucrose, was used in rooting experiments. The $\mathrm{pH}$ of the medium was adjusted to 5.8 before autoclaving at $121{ }^{\circ} \mathrm{C}$ and $1.05 \mathrm{~kg} \cdot \mathrm{cm}^{-2}$ pressure for $20 \mathrm{~min}$. All cultures were kept at $26 \pm 1{ }^{\circ} \mathrm{C}$ and a 16-h photoperiod with $25 \mu \mathrm{mol} \cdot \mathrm{m}^{-2} \cdot \mathrm{s}^{-1}$ irradiation provided by Philips $32-\mathrm{W}$ cool white fluorescent lamps (Philips Electric Company, Hyderabad, India). In all the experiments, the explants were cultured singly and vertically on $20 \mathrm{~cm}^{3}$ medium in glass test tube $(25 \times 150 \mathrm{~mm})$.

\section{Shoot development and elongation}

Initially, single-node segments of about $1 \mathrm{~cm}$ in length were used for the study. They were cultured for 3 weeks on BM media containing plant growth regulators (PGRs) at various concentrations and combinations. Then, for shoot elongation, shoot clumps (1-2 mm) developing on initial explants were excised and divided to have single shoot explants and cultured for elongation on BM without PGRs for further 3 weeks. In the first experiment, the elongated shoots were cultured on BM supplemented with different concentrations of benzyl aminopurine (BAP: 0.0, 2.0, 4.0, 6.0, 8.0 10.0, 12.0, and $16.0 \mathrm{mg} \cdot \mathrm{dm}^{-3}$ ) for shoot proliferation. At the second experiment, the shoot induction was stimulated by the combination of BAP $\left(4.0 \mathrm{mg} \cdot \mathrm{dm}^{-3}\right)$ and naphthalene acetic acid (NAA: 0.5, 1.0, 1.5, 2.0, 2.5, and $3.0 \mathrm{mg} \cdot \mathrm{dm}^{-3}$ ). In the third experiment, nodal segments were cultured on BM supplemented with $4.0 \mathrm{mg} \cdot \mathrm{dm}^{-3} \mathrm{BAP}, 2.0 \mathrm{mg} \cdot \mathrm{dm}^{-3} \mathrm{NAA}$ and different concentrations of zeatin $(0.5,1.0,1.5,2.0,2.5$, and $\left.3.0 \mathrm{mg} \cdot \mathrm{dm}^{-3}\right)$. In each experiment, observations were made on the survival of explants, frequency of explants forming shoots, number of shoots per explant, and average shoot length after 3 weeks of shoot elongation.

\section{Root induction}

Shoots (3-4 mm) for rooting experiments were derived from the medium containing $4.0 \mathrm{mg} \cdot \mathrm{dm}^{-3}$ BAP followed by shoot elongation on BM. In the first experiment, the shoots were transferred on RM containing six concentrations $(0.0,2.0,4.0,6.0,8.0$, and $10.0 \mathrm{mg} \cdot \mathrm{dm}^{-3}$ ) of zeatin. To determine the influence of IBA on root formation, the second experiment was conducted by transfer of shoots on RM medium supplemented with five concentrations $\left(0.5,1.0,1.5,2.0\right.$, and $\left.2.5 \mathrm{mg} \cdot \mathrm{dm}^{-3}\right)$ of 3-indolebutyric acid (IBA). In the third experiment, shoots were cultured on RM supplemented with 2.0 $\mathrm{mg} \cdot \mathrm{dm}^{-3}$ zeatin and $1.0,1.5$, and $2.0 \mathrm{mg} \cdot \mathrm{dm}^{-3} \mathrm{IBA}$. In all experiments, frequency of root formation and number of root per shoot were recorded after 3 weeks. 


\section{Hardening of plantlets and establishment in a greenhouse}

Plantlets $(4-5 \mathrm{~cm})$ with well-developed roots were rinsed with water to wash off the agar medium and transplanted to peat pellets (AS Jiffy Products Ltd, Norway) in plastic pots that were covered to maintain high humidity. Fifteen plantlets from each of rooting treatment were subjected to the hardening process. They were grown at $22-26{ }^{\circ} \mathrm{C}$ for 3 weeks and after that were transferred to the greenhouse.

\section{Molecular identity of microplants}

DNA was extracted from fresh leaves (1.0 $1.5 \mathrm{~g}$ ) of two plants per rooting treatment 7 weeks after soil establishment using the cetyl-trimethylammonium bromide (CTAB) method of Doyle and Doyle (1990). Quantification of DNA was done by a Nanodrop spectrophotometer (Nanodrop 1000, Thermo Fischer Scientific, Wilmington, USA). Four random primers (Table 1) were used based on RAPD results from other members of Asteraceae (Salvi et al. 2001). All reactions were repeated at least twice. RAPD amplification was carried out in $20-\mathrm{mm}^{3}$ reaction volume containing $25 \mathrm{ng}$ DNA $\left(2 \mathrm{~mm}^{3}\right), 2.0 \mathrm{~mm}^{3}$ of $10 \times$ polymerase chain reaction (PCR) buffer (Taq buffer A containing $\mathrm{MgCl}_{2}$ ), $0.5 \mathrm{~mm}^{3}$ of $100 \mu \mathrm{M}$ dNTP, $2.0 \mathrm{~mm}^{3}$ of RAPD primer, $0.3 \mathrm{~mm}^{3}$ of Taq DNA polymerase (Bioline Inc., Taunton, MA, USA), and water to make up the volume. The PCR program used was as described by Patamsyte et al. (2011). The PCR products obtained were separated on $1.5 \%$ agarose gel through electrophoresis using size standards GeneRuler $100 \mathrm{bp}$ DNA Ladder Plus and photographed using Gel Documentation System (Bio-Rad, Munchen, Germany).

Five ISSR primers were finally used in the study after an initial screening of 15 primers for the production of distinct and scorable bands (Table 1). Amplification was carried out in $25 \mathrm{~mm}^{3}$ reaction volume containing $1.5 \mathrm{~mm}^{3} \mathrm{MgCl}_{2}, 0.5 \mathrm{~mm}^{3}$ of $100 \mu \mathrm{M}$ dNTP, $2.0 \mathrm{~mm}^{3}$ of $10 \times$ PCR buffer, $2.0 \mathrm{~mm}^{3}$ of ISSR primers $(10 \mathrm{pM}), 0.3 \mathrm{~mm}^{3}$ of Taq DNA polymerase (Bioline, USA), and $20 \mathrm{ng}$ genomic DNA $\left(2 \mathrm{~mm}^{3}\right)$ as template and water to make up the volume. The PCR program used was as described by Patamsyte et al. (2011). The PCR products obtained were separated on $2 \%$ agarose gel through electrophoresis using size standards GeneRuler 100 bp
DNA Ladder Plus and photographed using Gel Documentation System (Bio-Rad, Munchen, Germany).

Table 1. Primers and amplification products of RAPDand ISSR-PCR used for the checking identity of micropropagated plants of Solanecio biafrae

\begin{tabular}{cllcc}
\hline s/n & Primer & Sequence & $\begin{array}{c}\text { Num- } \\
\text { ber of } \\
\text { bands }\end{array}$ & $\begin{array}{c}\text { Range of } \\
\text { applicon } \\
(\mathrm{pb})\end{array}$ \\
\hline 1. & OPB-01 & TTCGAGCCAG & 03 & $200-1000$ \\
\hline 2. & OPB-06 & TGCTCTGCCC & 03 & $250-1050$ \\
\hline 3. & OPK-01 & TGCCGAGCTG & 04 & $250-2000$ \\
\hline 4. & OPK-02 & GTGAGGCGTC & 05 & $450-3000$ \\
\hline 5. & UBC-836 & $(\mathrm{AG})_{8}$ YA & 04 & $325-1990$ \\
\hline 6. & UBC-843 & $(\mathrm{CT})_{8}$ RA & 06 & $350-1965$ \\
\hline 7. & UBC-857 & $(\mathrm{AC})_{8}$ YG & 08 & $200-2000$ \\
\hline 8. & UBC-859 & TG $)_{8}$ RC & 04 & $1340-3000$ \\
\hline 9. & UBC-860 & $(\mathrm{TG})_{8}$ RA & 05 & $330-400$
\end{tabular}

$\mathrm{R}=$ purines: $\mathrm{G}$ or $\mathrm{A} ; \mathrm{Y}=$ pyrimidines: $\mathrm{C}$ or $\mathrm{T} \mathrm{pb}-$ base pair

\section{Experimental design and statistical analysis}

In all experiments, treatments were arranged in a completely randomized design with 15 replicates (explants). Each experiment was repeated twice. Data were further subjected to analysis of variance to detect differences among treatments using PROC GLM procedure of the Statistical Analysis Systems (SAS 2002). Means were separated by Tukey's test at $5 \%$ level of probability.

\section{RESULTS AND DISCUSSION}

This work is the first report on in vitro propagation of S. biafrae; therefore, information at every stage is important for a successful application of tissue culture techniques for improvement of the crop. The disinfection procedure described earlier yielded nearly $98 \%$ aseptic bud cultures, while explant discoloration was $0.5 \%$.

After 2 weeks of culture, surviving nodal segments retained their green appearance, while explants that could not survive turned brown or yellow. Survival of nodal segments, frequency of explants forming shoots, number of shoot per explant, and shoot length as influenced by BAP alone is presented in Table 2. Shoot formation was not observed on medium free of BAP. The highest survival of explants 
was in the presence of BAP at a concentration of 4.0 and $6.0 \mathrm{mg} \cdot \mathrm{dm}^{-3}$. However, the highest number of shoots and the longest shoots were obtained using $4 \mathrm{mg} \cdot \mathrm{dm}^{-3}$ BAP. Compared to the treatments with BAP alone, an improvement in explant survival and shoot length was observed after the addition of NAA to BAP medium (Table 3). However, there was no significant difference among NAA treatments in the number of shoots per explant (Table 3). The highest survival rate and the growth of shoots were observed on medium containing $4.0 \mathrm{mg} \cdot \mathrm{dm}^{-3}$ BAP and $2.0 \mathrm{mg} \cdot \mathrm{dm}^{-3} \mathrm{NAA}$.
Further improvement of shoot development from nodal explants was obtained when BM containing $4.0 \mathrm{mg} \cdot \mathrm{dm}^{-3} \mathrm{BAP}$ and $2.0 \mathrm{mg} \cdot \mathrm{dm}^{-3} \mathrm{NAA}$ was supplemented with zeatin. Addition of this cytokinin resulted in markedly higher number of shoots per explant (3.0-3.4) compared to those recorded in the presence of BAP alone or BAP combined with NAA (Table 3). In all zeatin treatments, $100 \%$ survival of explants was observed, with formation of shoots on more than $70 \%$ of explants. All explants grown on the medium containing $1 \mathrm{mg} \cdot \mathrm{dm}^{-3}$ zeatin formed shoots (Table 4).

Table 2. Effect of BAP on shoot development from initial explants (nodal segments) of Solanecio biafrae

\begin{tabular}{ccccc}
\hline $\begin{array}{c}\text { BAP } \\
\left(\mathrm{mg} \cdot \mathrm{dm}^{-3}\right)\end{array}$ & $\begin{array}{c}\text { Survival } \\
(\%)\end{array}$ & $\begin{array}{c}\text { Explants forming } \\
\text { shoots }(\%)\end{array}$ & $\begin{array}{c}\text { Number of shoots } \\
\text { per explant }\end{array}$ & Shoot length (mm) \\
\hline 0.0 & $85.5 \pm 6.7 \mathrm{~b}$ & $0.0 \pm 0.0 \mathrm{~d}$ & - & - \\
\hline 2.0 & $87.5 \pm 7.2 \mathrm{~b}$ & $43.8 \pm 4.8 \mathrm{c}$ & $1.3 \pm 0.6 \mathrm{c}$ & $3.7 \pm 1.2 \mathrm{~b}$ \\
\hline 4.0 & $98.6 \pm 7.4 \mathrm{a}$ & $75.4 \pm 7.1 \mathrm{a}$ & $2.4 \pm 0.8 \mathrm{~b}$ & $8.5 \pm 2.4 \mathrm{a}$ \\
\hline 6.0 & $98.2 \pm 6.2 \mathrm{a}$ & $73.6 \pm 7.6 \mathrm{a}$ & $1.2 \pm 0.5 \mathrm{c}$ & $4.6 \pm 0.8 \mathrm{~b}$ \\
\hline 8.0 & $83.2 \pm 6.8 \mathrm{~b}$ & $65.3 \pm 5.5 \mathrm{~b}$ & $1.2 \pm 0.3 \mathrm{c}$ & $3.8 \pm 0.8 \mathrm{~b}$ \\
\hline 10.0 & $80.1 \pm 5.6 \mathrm{~b}$ & $64.5 \pm 5.3 \mathrm{~b}$ & $1.0 \pm 0.6 \mathrm{c}$ & $4.5 \pm 1.3 \mathrm{~b}$ \\
\hline 12.0 & $81.5 \pm 6.5 \mathrm{~b}$ & $60.7 \pm 5.4 \mathrm{~b}$ & $1.0 \pm 0.5 \mathrm{c}$ & $4.3 \pm 1.2 \mathrm{~b}$ \\
\hline 14.0 & $85.7 \pm 5.8 \mathrm{~b}$ & $57.9 \pm 4.7 \mathrm{~b}$ & $1.0 \pm 0.4 \mathrm{c}$ & $4.6 \pm 0.7 \mathrm{~b}$ \\
\hline 16.0 & $84.6 \pm 5.4 \mathrm{~b}$ & $52.8 \pm 4.6 \mathrm{~b}$ & $1.0 \pm 0.5 \mathrm{c}$ & $3.8 \pm 0.6 \mathrm{~b}$ \\
\hline
\end{tabular}

Values are means ( \pm standard error). Means followed by different letters in same column are significantly different at $5 \%$ level of probability according to Tukey's Test.

Table 3. Effect of NAA combined with $4 \mathrm{mg} \cdot \mathrm{dm}^{-3}$ BAP on shoot development from initial explants of Solanecio biafrae

\begin{tabular}{ccccc}
\hline $\begin{array}{c}\text { NAA } \\
\left(\mathrm{mg} \cdot \mathrm{dm}^{-3}\right)\end{array}$ & $\begin{array}{c}\text { Survival } \\
(\%)\end{array}$ & $\begin{array}{c}\text { Explants forming } \\
\text { shoots }(\%)\end{array}$ & $\begin{array}{c}\text { Number of shoots } \\
\text { per explant }\end{array}$ & Shoot length $(\mathrm{mm})$ \\
\hline 0.5 & $95.6 \pm 5.6 \mathrm{~b}$ & $54.4 \pm 4.8 \mathrm{~d}$ & $2.4 \pm 0.8 \mathrm{a}$ & $3.8 \pm 1.2 \mathrm{~d}$ \\
\hline 1.0 & $95.8 \pm 6.8 \mathrm{~b}$ & $75.2 \pm 4.6 \mathrm{~b}$ & $2.0 \pm 0.6 \mathrm{a}$ & $15.2 \pm 2.6 \mathrm{~b}$ \\
\hline 1.5 & $95.8 \pm 6.3 \mathrm{~b}$ & $78.0 \pm 6.5 \mathrm{~b}$ & $2.0 \pm 0.7 \mathrm{a}$ & $10.2 \pm 3.3 \mathrm{c}$ \\
\hline 2.0 & $100.0 \pm 0.0 \mathrm{a}$ & $84.0 \pm 6.2 \mathrm{a}$ & $2.2 \pm 0.9 \mathrm{a}$ & $10.2 \pm 3.2 \mathrm{c}$ \\
\hline 2.5 & $100.0 \pm 0.0 \mathrm{a}$ & $68.8 \pm 6.2 \mathrm{c}$ & $2.2 \pm 0.5 \mathrm{a}$ & $18.6 \pm 3.8 \mathrm{a}$ \\
\hline 3.0 & $100.0 \pm 0.0 \mathrm{a}$ & $63.7 \pm 5.7 \mathrm{c}$ & $2.2 \pm 0.4 \mathrm{a}$ & $12.8 \pm 2.7 \mathrm{~b}$ \\
\hline
\end{tabular}

Explanation: see Table 2. 
Table 4: Effect of zeatin combined with $4 \mathrm{mg} \cdot \mathrm{dm}^{-3}$ BAP and $2 \mathrm{mg} \cdot \mathrm{dm}^{-3}$ NAA on shoot development of Solanecio biafrae

\begin{tabular}{ccccc}
\hline $\begin{array}{c}\text { Zeatin } \\
\left(\mathrm{mg} \cdot \mathrm{dm}^{-3}\right)\end{array}$ & $\begin{array}{c}\text { Survival } \\
(\%)\end{array}$ & $\begin{array}{c}\text { Explants forming } \\
\text { shoots }(\%)\end{array}$ & $\begin{array}{c}\text { Number of shoots } \\
\text { per explant }\end{array}$ & Shoot length (mm) \\
\hline 0.5 & $100.0 \pm 0.0 \mathrm{a}$ & $98.2 \pm 7.8 \mathrm{~b}$ & $3.2 \pm 1.1 \mathrm{a}$ & $10.2 \pm 3.5 \mathrm{c}$ \\
\hline 1.0 & $100.0 \pm 0.0 \mathrm{a}$ & $100.0 \pm 0.0 \mathrm{a}$ & $3.4 \pm 0.8 \mathrm{a}$ & $22.0 \pm 6.8 \mathrm{a}$ \\
\hline 1.5 & $100.0 \pm 0.0 \mathrm{a}$ & $88.7 \pm 5.8 \mathrm{c}$ & $3.0 \pm 1.0 \mathrm{a}$ & $20.0 \pm 4.1 \mathrm{a}$ \\
\hline 2.0 & $100.0 \pm 0.0 \mathrm{a}$ & $81.3 \pm 5.2 \mathrm{c}$ & $3.2 \pm 0.7 \mathrm{a}$ & $19.8 \pm 3.8 \mathrm{~b}$ \\
\hline 2.5 & $100.0 \pm 0.0 \mathrm{a}$ & $75.5 \pm 6.4 \mathrm{~d}$ & $3.0 \pm 0.9 \mathrm{a}$ & $15.4 \pm 3.7 \mathrm{c}$ \\
\hline 3.0 & $100.0 \pm 0.0 \mathrm{a}$ & $74.8 \pm 6.3 \mathrm{~d}$ & $3.0 \pm 0.8 \mathrm{a}$ & $15.8 \pm 3.6 \mathrm{c}$ \\
\hline
\end{tabular}

Explanation: see Table 2.

BAP - benzyl amino purine NAA - naphthalene acetic acid

Micropropagation of members of Asteraceae family has been reported from various explants such as flower stalk, nodal segment, cotyledon, shoot, and leaf explants (Rossato et al. 2015; Lucchesini et al. 2009; Hristova et al. 2013; Subhan \& Agrawal 2011). Our observation that the best survival of explants occurred at 4.0 and $6.0 \mathrm{mg} \cdot \mathrm{dm}^{-3}$ BAP confirmed the reports of Lucchesini et al. (2009) on Echinacea angustifolia. On the other hand, Hristova et al. (2013) reported that the presence of PGRs in medium had no effect on explant survival of Artemisia chamaemelifolia. Furthermore, shoot induction in the presence of BAP observed in current work agrees with previous works. For example, MS medium supplemented with BAP alone produced high shoot induction and multiplication rate in some Asteraceae members such as Wedelia calendulacea (Emmanuel et al. 2000), Echinacea purpurea (Korochi et al. 2002), and Carlina acaulis (Grubisić

Table 5: Effect of zeatin alone on root formation, number of roots per plantlet and plantlet acclimatization in Solanecio biafrae

\begin{tabular}{cccc}
\hline $\begin{array}{c}\text { Zeatin } \\
\left(\mathrm{mg} \cdot \mathrm{dm}^{-3}\right)\end{array}$ & $\begin{array}{c}\text { Root for- } \\
\text { mation }(\%)\end{array}$ & $\begin{array}{c}\text { Number of } \\
\text { roots per } \\
\text { shoot }\end{array}$ & $\begin{array}{c}\text { Plantlet ac- } \\
\text { climatization } \\
(\%)\end{array}$ \\
\hline 0.0 & $75.6 \pm 6.8 \mathrm{a}$ & $4.2 \pm 0.8 \mathrm{a}$ & $52.8 \pm 4.4 \mathrm{c}$ \\
\hline 2.0 & $63.3 \pm 5.6 \mathrm{~b}$ & $4.3 \pm 1.0 \mathrm{a}$ & $87.3 \pm 6.3 \mathrm{a}$ \\
\hline 4.0 & $51.8 \pm 6.5 \mathrm{ab}$ & $3.6 \pm 0.7 \mathrm{c}$ & $88.2 \pm 5.6 \mathrm{a}$ \\
\hline 6.0 & $45.3 \pm 4.8 \mathrm{c}$ & $4.0 \pm 0.7 \mathrm{ab}$ & $73.5 \pm 6.0 \mathrm{~b}$ \\
\hline 8.0 & $42.3 \pm 3.6 \mathrm{c}$ & $4.3 \pm 0.8 \mathrm{a}$ & $74.8 \pm 5.8 \mathrm{~b}$ \\
\hline 10.0 & $42.8 \pm 3.5 \mathrm{c}$ & $4.3 \pm 2.3 \mathrm{a}$ & $73.4 \pm 5.9 \mathrm{~b}$ \\
\hline
\end{tabular}

Explanation: see Table 2. et al. 2004). Marked improvement of shoot development from initial explants was recorded when $4.0 \mathrm{mg} \cdot \mathrm{dm}^{-3}$ BAP was combined with different concentrations of NAA. Such synergetic effect of BAP and NAA was also reported in other micropropagated plant species belonging to Asteraceae family (Jain et al. 2008; Trejgell et al. 2010; Joshi et al. 2015).

Before rooting, the induced shoots were separated and transferred to basal medium for elongation. Table 5 presents the effect of zeatin alone on shoot rooting. Most root formation (75.6\%) was observed on the medium free of zeatin, while its addition decreased rooting by $12-33 \%$. However, plantlet acclimatization was the poorest when they were rooted on this medium (52.8\%). Most plantlets that successfully acclimatized were from media containing 2 and $4 \mathrm{mg} \cdot \mathrm{dm}^{-3}$ zeatin $(94.3 \%$ and $97.6 \%$, respectively). Zeatin had no effect on the number of roots. Root formation was promoted by IBA (Table 6).

Table 6: Effect of IBA alone on root formation, number of roots per plantlet and plantlet acclimatization in Solanecio biafrae

\begin{tabular}{cccc}
\hline $\begin{array}{c}\text { IBA } \\
\left(\mathrm{mg} \cdot \mathrm{dm}^{-3}\right)\end{array}$ & $\begin{array}{c}\text { Root for- } \\
\text { mation }(\%)\end{array}$ & $\begin{array}{c}\text { Number of } \\
\text { roots per } \\
\text { shoot }\end{array}$ & $\begin{array}{c}\text { Plantlet ac- } \\
\text { climatization } \\
(\%)\end{array}$ \\
\hline 0.0 & $75.3 \pm 5.4 \mathrm{~b}$ & $4.3 \pm 0.9 \mathrm{ab}$ & $54.5 \pm 0.8 \mathrm{~b}$ \\
\hline 0.5 & $71.3 \pm 6.8 \mathrm{ab}$ & $5.4 \pm 1.8 \mathrm{a}$ & $94.3 \pm 8.5 \mathrm{a}$ \\
\hline 1.0 & $87.8 \pm 7.1 \mathrm{a}$ & $6.5 \pm 1.4 \mathrm{a}$ & $97.6 \pm 10.2 \mathrm{a}$ \\
\hline 1.5 & $88.3 \pm 6.8 \mathrm{a}$ & $5.0 \pm 1.1 \mathrm{a}$ & $93.7 \pm 9.4 \mathrm{a}$ \\
\hline 2.0 & $87.5 \pm 7.2 \mathrm{a}$ & $4.3 \pm 0.8 \mathrm{ab}$ & $97.8 \pm 9.2 \mathrm{a}$ \\
\hline 2.5 & $86.1 \pm 7.4 \mathrm{a}$ & $4.2 \pm 0.7 \mathrm{ab}$ & $93.7 \pm 9.8 \mathrm{a}$ \\
\hline
\end{tabular}

Explanation: see Table 2. 
Table 7: Effect of IBA combined with $2 \mathrm{mg} \cdot \mathrm{dm}^{-3}$ zeatin on root formation, number of roots per plantlet and plantlet acclimatization in Solanecio biafrae

\begin{tabular}{cccc}
\hline $\begin{array}{c}\text { IBA } \\
\left(\mathrm{mg} \cdot \mathrm{dm}^{-3}\right)\end{array}$ & $\begin{array}{c}\text { Root for- } \\
\text { mation }(\%)\end{array}$ & $\begin{array}{c}\text { Number of } \\
\text { roots per ex- } \\
\text { plant }\end{array}$ & $\begin{array}{c}\text { Plantlet ac- } \\
\text { climatization } \\
(\%)\end{array}$ \\
\hline 1.0 & $43.8 \pm 3.2 \mathrm{a}$ & $3.8 \pm 0.7 \mathrm{a}$ & $100.0 \pm 0.0 \mathrm{a}$ \\
\hline 1.5 & $40.7 \pm 3.4 \mathrm{a}$ & $3.8 \pm 0.6 \mathrm{a}$ & $100.0 \pm 0.0 \mathrm{a}$ \\
\hline 2.0 & $32.5 \pm 3.2 \mathrm{ab}$ & $3.6 \pm 0.6 \mathrm{a}$ & $100.0 \pm 0.0 \mathrm{a}$ \\
\hline
\end{tabular}

Values are means ( \pm standard error). Means followed by different letters in same column are significantly different at 5\% level of probability according to Tukey's Test.

The addition 1.0 to $2.5 \mathrm{mg} \cdot \mathrm{dm}^{-3}$ IBA increased significantly root formation by $13-15 \%$ and acclimatization by $42-44 \%$ in comparison with control (no IBA). IBA did not affect root number. Zeatin and IBA combinations did not have a positive effect on rooting. Less than $44 \%$ of shoots formed roots and their number per shoot was lower than that without zeatin at the same IBA concentration (Table 7).
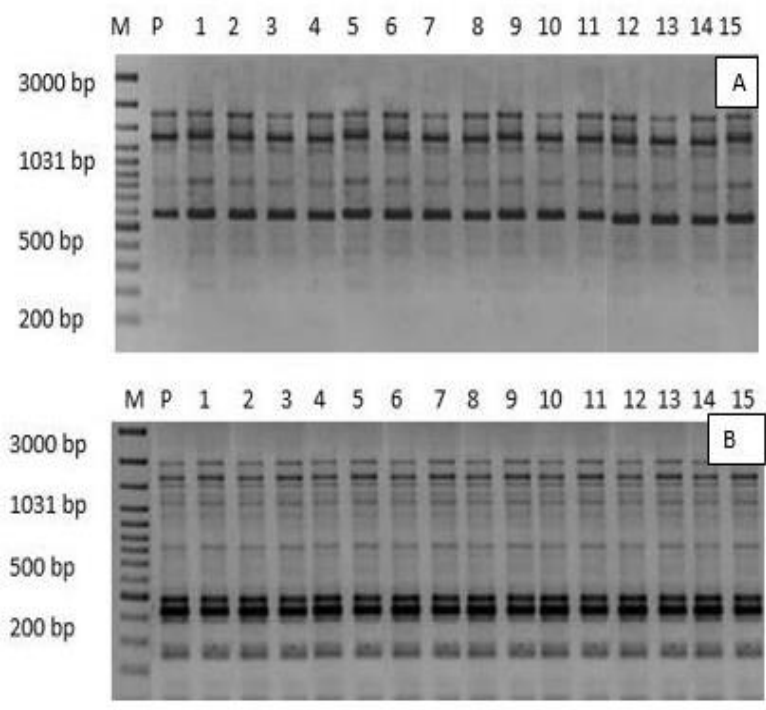

Fig. 1. RAPD analysis with the primer OPK-02 (A) and ISSR analysis with the primer UBC 857 (B) M - GeneRuler ladder, $\mathrm{P}$ - Donor plant, $1-0.0 \mathrm{mg} \cdot \mathrm{dm}^{-3}$ zeatin, $2-$ $2.0 \mathrm{mg} \cdot \mathrm{dm}^{-3}$ zeatin, $3-4.0 \mathrm{mg} \cdot \mathrm{dm}^{-3}$ zeatin, $4-$ $6.0 \mathrm{mg} \cdot \mathrm{dm}^{-3}$ zeatin, $5-8.0 \mathrm{mg} \cdot \mathrm{dm}^{-3}$ zeatin, $6-$ $10.0 \mathrm{mg} \cdot \mathrm{dm}^{-3}$ zeatin, $7-0.0 \mathrm{mg} \cdot \mathrm{dm}^{-3}$ IBA, $8-$ $0.5 \mathrm{mg} \cdot \mathrm{dm}^{-3} \mathrm{IBA}, 9-1.0 \mathrm{mg} \cdot \mathrm{dm}^{-3} \mathrm{IBA}, 10-1.5 \mathrm{mg} \cdot \mathrm{dm}^{-3}$ IBA, $11-2.0 \mathrm{mg} \cdot \mathrm{dm}^{-3} \mathrm{IBA}, 12-2.5 \mathrm{mg} \cdot \mathrm{dm}^{-3} \mathrm{IBA}, 13-$ $2.0 \mathrm{mg} \cdot \mathrm{dm}^{-3}$ zeatin $+1.0 \mathrm{mg} \cdot \mathrm{dm}^{-3} \mathrm{IBA}, 14-2.0 \mathrm{mg} \cdot \mathrm{dm}^{-3}$ zeatin $+1.5 \mathrm{mg} \cdot \mathrm{dm}^{-3} \mathrm{IBA}, 15-2.0 \mathrm{mg} \cdot \mathrm{dm}^{-3}$ zeatin + $2.0 \mathrm{mg} \cdot \mathrm{dm}^{-3} \mathrm{IBA}$.
Some members of Asteraceae developed in vitro roots on medium free of PGRs, while others required the presence of PGRs in medium to form roots. In this study, the presence or absence of PGRs in the rooting medium did not always produce the expected results. For instance, av. $76.9 \%$ of shoots produced roots in the absence of PGRs with moderate (av. 53.2\%) plantlet acclimatization. In the presence of zeatin, root formation decreases, while acclimatization reached $100 \%$. In addition, the rate of acclimatized microplants increased to $100 \%$ when rooted on IBA containing media. Clearly, our data suggested that IBA is the most suitable PGR for rooting of S. biafrae. The presence of IBA has been reported to increase the number of rooted shoots as well as the number of roots per shoot in Saussurea obvallata (Joshi \& Dhar 2003). The incidence of root formation on auxin-free medium may be due to the presence of endogenous auxin in regenerated shoots. In agreement with our observation on plantlet acclimatization, microplants of members of Asteraceae (Senecio macrophyllus and Spilanthes acmella) have been reported to exhibit $100 \%$ plantlet acclimatization (Trejgell et al. 2010; Joshi et al. 2015). Genetic stability of the micropropagated plants was confirmed by RAPD and ISSR analyses. Twelve random RAPD primers were screened, of which four (OPB-01, OPB-06, OPK-01, OPK-02) produced clear, distinct, and scorable bands. A total of 240 bands were obtained and primer OPK-02 generated the highest number of bands (5) (Fig. 1A). From 15 ISSR primers, 5 (UBC-836, UBC-843, UBC857, UBC-859, and UBC-860) produced distinct and scorable bands. A total of 405 bands were obtained, and primer UBC 857 produced the highest (8) number of bands (Fig. 1B). DNA amplification profiles of both RAPD and ISSR primers revealed similarity in banding patterns among micropropagated plants. Similarly, no variation in banding pattern was observed between the mother plant and the micropropagated plants. This indicates identity at DNA level among micropropagated plants and between the micropropagated plants and their donors. Both RAPD and ISSR markers have been successfully applied to check the genomic identity of micropropagated plants of Asteraceae. Martins et al. (2004) suggested that a better analysis of genetic 
stability of plantlets can be made by using a combination of two types of markers that amplify different regions of the genome (Salvi et al. 2001; Patamsyte et al. 2011). True-to-type clonal fidelity is one of the most important prerequisites in the micropropagation of any crop species. Sometimes, the presence of somaclonal variation among subclones of one parental line, arising as a direct consequence of in vitro culture of plant cells, tissues, or organs, was reported. Using shoot propagation and rooting described here, no variation in the banding patterns was detected what clearly indicates that in vitro conditions applied in this study do not induce any genetic variability in $S$. biafrae.

\section{CONCLUSION}

In conclusion, this is the first report of in vitro propagation of S. biafrae (Oliv. \& Hiern) C. Jeffrey. Our data suggested that shoot development was best on MS medium fortified with $4.0 \mathrm{mg} \cdot \mathrm{dm}^{-3} \mathrm{BAP}$, $2.0 \mathrm{mg} \cdot \mathrm{dm}^{-3} \mathrm{NAA}$, and $1.0 \mathrm{mg} \cdot \mathrm{dm}^{-3}$ zeatin and rooting preferable on half-strength MS supplemented with $1 \mathrm{mg} \cdot \mathrm{dm}^{-3}$ IBA. The protocol developed here is simple and can be used for the sustainable supply of genetically stable in vitro plant materials with the prospect to apply in plant propagation and biotechnology. Furthermore, the protocol described here opens a pathway for in vitro conservation of $S$. biafrae by apical and nodal segments. In addition, the protocol may promote germplasm exchange for production, improvement, and conservation of the vegetable. More importantly, our work may facilitate in vitro production of phytochemicals with medicinal properties isolated from $S$. biafrae by pharmaceutical industry.

\section{Acknowledgment}

The authors appreciate the support of Dr. O.O. Oyelakin, Biotechnology Centre, Federal University of Agriculture, Abeokuta, Nigeria and National Centre for Genetic Resources and Biotechnology, Ibadan, Nigeria, for this study.

\section{REFERENCES}

Adebooye O.C. 1996. Proximate composition and nu-trient analyses of six selected leaf vegetables of
Southwest Nigeria. Ife Journal of Agriculture 18: 56-62.

Adebooye O.C. 2004. Solanecio biafrae (Oliv. \& Hiern) C. Jeffrey. In: Grubben G.J.H., Denton O.A. (Eds.), Plant Resources of Tropical Africa 2: Vegetables. Backhuys Publishers, Netherlands, pp. 469-471.

Adebooye O.C., Opabode J.T. 2004. Status of conser-vation of the indigenous leaf vegetables and fruits of Africa. African Journal of Biotechnology 3: 700705. DOI: 10.5897/AJB2004.000-2133.

Das A., Gantait S., Mandal N. 2011. Micropropagation of an elite medicinal plant: Stevia rebaudiana Bert. International Journal of Agricultural Re-search 6: 40-48. DOI: 10.3923/ijar.2011.40.48.

Doyle J.J., Doyle I.L. 1990. Isolation of DNA from fresh tissue. Focus 12: 13-15.

Emmanuel S., Ignacimuthu S., Kathiravan K. 2000. Micropropagation of Wedelia calendulacea Less., a medicinal plant. Phytomorphology 50: 195-200.

Grubišić D., Šavikin-Fodulović K., Mišić D., Giba Z., Konjević R. 2004. In vitro stem elongation of stemless carline thistle. Plant Growth Regulation 44: 6569. DOI: 10.1007/s10725-004-2602-7.

Hristova L., Damyanova E., Doichinova Z., KapchinaToteva V. 2013. Effect of 6-benzylaminopurine on micropropagation of Artemisia chamaemelifo-lia Vill. (Asteraceae). Bulgarian Journal of Agricul-tural Science 19: 57-60.

Jain P., Kachhwaha S., Kothari S.L. 2009. Improved micropropagation protocol and enhancement in biomass and chlorophyll content in Stevia rebau-diana (Bert.) Bertoni by using high copper levels in the culture medium. Scientia Horticulturae 119: 315 319. DOI: 10.1016/j.scienta.2008.08.015.

Joshi V., Tiwari K.L., Jadhav S.K. 2015. In vitro propagation of Spilanthes acmella (L.) Murray using semisolid and liquid medium. Indian Journal of Biotechnology 14: 112-116.

Joshi M., Dhar U. 2003. In vitro propagation of Saussurea obvallata (DC.) Edgew. - an endangered ethnoreligious medicinal herb of Himalaya. Plant Cell Reports 21: 933-939. DOI: 10.1007/s00299-0030601-1.

Koroch A., Juliani H.R., Kapteyn J., Simon J.E. 2002. In vitro regeneration of Echinacea purpurea from leaf explants. Plant Cell, Tissue and Organ Culture 69: 79-83. DOI: 10.1023/A:1015042032091.

Lucchesini M., Bertoli A., Mensuali-Sodi A., Pistelli L. 2009. Establishment of in vitro tissue cultures from Echinacea angustifolia D.C. adult plants for the production of phytochemicals compounds. Scientia 
Horticulturae 122: 484-490. DOI: $10.1016 / \mathrm{J}$.scienta.2009.06.011.

Martins M., Sarmento D., Oliveira M.M. 2004. Genetic stability of micropropagated almond plantlets, as assessed by RAPD and ISSR markers. Plant Cell Reports 23: 492-496. DOI: 10.1007/s00299-004-0870-3.

Murashige T., Skoog F. 1962. A revised medium for rapid growth and bio assays with tobacco tissue cultures. Physiologia Plantarum 15: 473-497. DOI: 10.1111/j.1399-3054.1962.tb08052.x.

Opabode J.T., Adebooye O.C. 2005. Application of biotechnology for the improvement of Nigerian indigenous leaf vegetables. African Journal of Biotechnology 4(3): 138-142. DOI: 10.5897/AJB2005.000-3028.

Patamsytė J., Čèsnienė T., Naugžemys D., Kleizaitė V., Vaitkūnienè V., Rančelis V., Žvingila D. 2011. Genetic diversity of warty cabbage (Bunias oriental-is L.) revealed by RAPD and ISSR markers. Žemdirbystė - Agriculture 98(3): 293-300.

Rossato L.V., Canto-Dorow T.S., Nicoloso F.T. 2015. Micropropagation of Pluchea sagittalis (Lam.)
Cabrera. Revista Brasileira de Plantas Medicinais 17: 239-245. DOI: 10.1590/1983-084X/13_106.

Salvi N.D., George L., Eapen S. 2001. Plant regeneration from leaf base callus of turmeric and random amplified polymorphic DNA analysis of regener-ated plants. Plant Cell, Tissue and Organ Culture 66: 113-119. DOI: 10.1023/A:1010638209377.

SAS Institute Inc. 2002. SAS/STAT User's Guide, version 6, fourth edition; vol. 1. Cary, N.C.

Shippers R.R. 2000. African indigenous vegetables: an overview of the cultivated species. Natural Resources Institute, London, UK, 214 p.

Subhan S., Agrawal V. 2011. Efficient in vitro micropropagation of purple fleabane (Vernonia an-thelmintica Willd.): a multipurpose under-exploited oil-yielding herb. International Journal of Pharma and Bio Sciences 2(4): B 231-241.

Trejgell A., Michalska M., Tretyn A. 2010. Micropropagation of Senecio macrophyllus M. Bieb. Acta Biologica Cracoviensia, Series Botanica 52: 67-72. DOI: 10.2478/v10182-010-0009-5. 